\title{
How can farmers be better integrated into nature parks? AgriPark - Transdiscipli- nary development of approaches for better cooperation between agriculture and Regional Nature Parks
}

\author{
Sonja Trachsel, Ruth Moser, Birgit Reutz \& Rebecca Göpfert
}

Keywords: participation, acceptance, sustainable development, agriculture, protected areas, Regional Nature Parks, Switzerland

\section{Abstract}

In the AgriPark project, a transdisciplinary approach was used to develop ways of integrating agriculture better into Regional Nature Parks. It revealed that there are no ready-made solutions and longer processes involving a wide range of stakeholders are needed to develop closer cooperation between parks and agriculture.
Profile

Protected area

Regional Nature Parks

Binntal, Gantrisch and

Schaffhausen

Mountain range

Alps, Switzerland

\section{Introduction}

Agriculture is an important player in Regional $\mathrm{Na}$ ture Parks (RNPs) in Switzerland. Farmers cultivate land and contribute with their activities to the improvement of biodiversity and the protection of landscapes, at the same time RNPs provide farmers with opportunities to further develop their farm businesses, for example, through the creation of cooperation projects or sales opportunities for agricultural products and services. However, farmers are frequently not ready to take advantage of these opportunities and to participate in RNP projects because of scepticism about the concept and usefulness of RNPs (Butticaz 2013; Haggenmacher 2017; Humer-Gruber 2016). The question that therefore arises is: How can farmers be convinced of the benefits of RNPs and the opportunities they offer? Currently there is no overview of tried and tested approaches for integrating agriculture better into RNPs that could be made available to agricultural advisory services and RNP managements.

\section{Transdisciplinary methodological approach}

Approaches to improve cooperation between agriculture and RNPs were developed in the AgriPark project using a transdisciplinary research methodology. The project team included experts from research $(\mathrm{Zu}-$ rich University of Applied Sciences ZHAW) and from the Swiss Association for the Development of Agriculture and Rural Areas, AGRIDEA, thus ensuring the link between research and practice. At the strategic level, project partners from the Federal Office of Agriculture, cantonal agricultural advisory services and the Network of the Swiss RNPs gave their feedback on the project. At the operational level, stakeholders from the three partner RNPs, Binntal, Gantrisch and Schaffhausen, were involved in workshops as part of the preliminary study as well as in the development of approaches for better cooperation between agriculture and RNPs. These approaches will be made available to the agricultural advisory services and RNP management teams.

The AgriPark project was divided into two phases (see Figure 1). In the first project phase quantitative and qualitative data were collected in the three Swiss partner RNPs, Binntal, Gantrisch, Schaffhausen. 1) An online survey was conducted in spring 2019 in the three RNPs by means of convenience sampling. Any farmer that was eligible for direct payments and had an e-mail address could take part. 509 farmers answered the questionnaire, at least in part, with a response rate of $36 \%$. Participants were asked if their farm was run by a man or a woman. $89 \%$ of those who answered this question indicated a man as primary farmer $(\mathrm{n}=279)$ and $71 \%$ a woman as secondary farm manager $(n=173)$. From this we concluded that the majority considered themselves as managing the farm as a couple. 2) Semi-structured interviews were also conducted in all three RNPs. To include different perspectives, the following stakeholders were interviewed in winter 2018 / spring 2019 using purposive sampling: 13 interviews with male farmers and 4 with farming couples, interviews with 5 female and 2 male representatives of the RNP management teams and with 4 male and 1 female representative(s) of the cantonal agricultural advisory services.

In the second phase we developed step by step approaches for a better integration of agriculture in RNPs. The results from the survey and interviews 


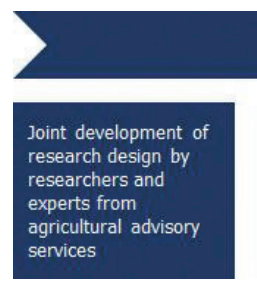

Phase 1: Pre-study

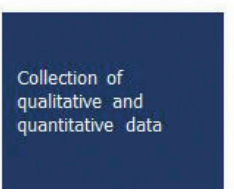

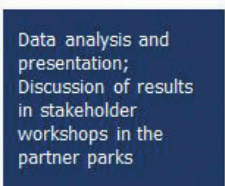
presentation;
Discussion of results in stakeholder partner parks

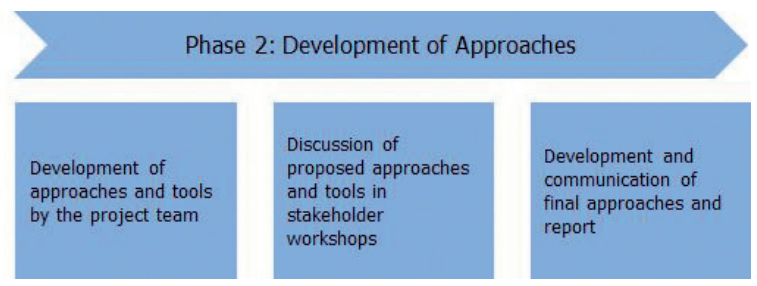

Figure 1 - Process of the AgriRNP Project, (own illustration).

served to elaborate paths of action. These were then discussed and further developed in two rounds of workshops in the participating RNPs and a further RNP in French-speaking Switzerland. Representatives of the RNPs, agriculture and agricultural advisory services were present at all of the workshops.

To develop possible approaches, we worked with buman-centred design, a creative, problem-solving process for developing innovative ideas that puts people and their problems and needs at the centre (IDEO. org 2015). In addition, Dave Snowden's Cynefin Framework served to classify problems and possible solutions depending on their context. While complicated problems can be solved with expert knowledge, complex problems need participatory approaches (Snowden et al. 2007).

\section{Results of the pre-study and paths of action}

The results showed that most farmers tend to assume the benefits of a RNP for agriculture as rather low. Nor do they rate their knowledge of the RNPs very highly. The analysis of the guided interviews indicates that the RNP managers need to do a lot of communication work to convince farmers to participate in the RNP. Figure 2 illustrates a RNP's possible agriculture-related activities and how farmers rate them according by significance (for more results, see Trachsel et al. 2020). $1^{\text {st }}$ path of action: Knowledge of needs and creation of proximity

Our research revealed that the relations between farmers and their RNPs differed from RNP to RNP. Factors influencing these relations were the history of the RNP, existing regional development projects, size of the RNP, and implemented agricultural projects in the RNP. Accordingly, activities in the RNPs were rated differently in the different RNPs. For instance, information on funding opportunities for agriculture (Figure 2) was very important for $46 \%$ in Binntal RNP ( $n=11)$, but for only $16 \%$ in Schaffhausen $(n=128)$. Consequently, in order to ascertain farmers' most pressing needs, RNP managers must develop close relations with farmers and gain their trust.

The survey and interviews suggest that the more contact farmers have with the RNP management, the more positively they judge the RNP's actions and achievements. Figure 3 shows: $58 \%$ of farmers who take advantage of RNP activities agree with the statement RNP XY contributes to the good image of agricultural products and services in the RNP, compared to only 38\% for farmers who do not participate in any RNP activities.

$2^{\text {nd }}$ path of action: Promotion of agricultural products \& services

The results of the online survey and the guided interviews showed that the farmers saw the RNP's

Information on funding opportunities for agriculture

Support for direct marketing

Support for the development of tourist services

Continuing training in the marketing of regional products

Support with spatial and land use planning issues

Support with project submission and project implementation

Continuing training on regional cooperation for farmers

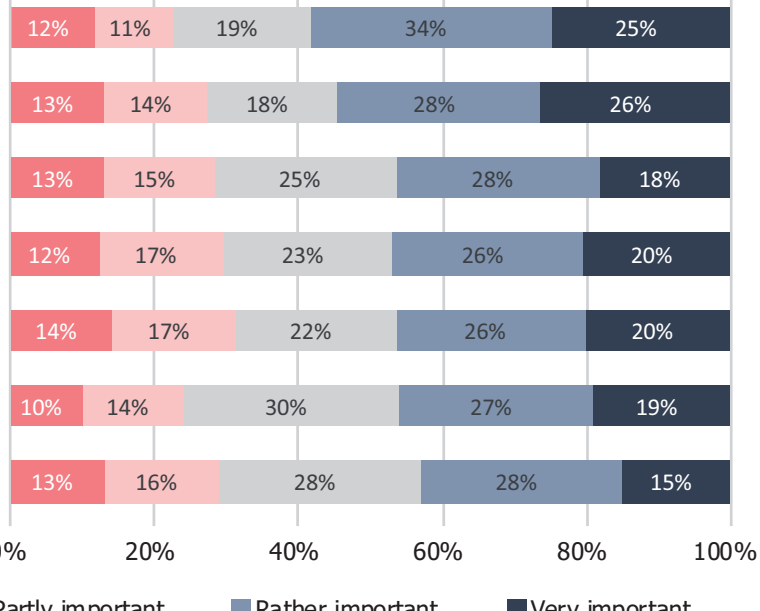

Completely unimportant Less important Partly important Rather important $\quad$ Very important

Figure 2 - Frequencies of the answers regarding the importance of different possible Regional Nature Park (RNP) activities for agriculture in the three RNPs $(n=330)$. Based on the results, we derived six paths of action showing where most action is needed or where there is potential for farmers to be better integrated into RNP activities. 
I use at least one activity that the nature park offers to agriculture $(n=267)$

I do not use any activity that the nature park offers to agriculture

$$
(n=96)
$$

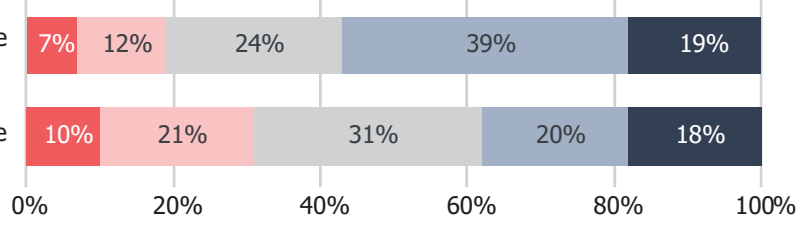

- Strongly disagree Disagree Partially agree Agree @ Strongly agree

Figure 3 - Evaluation of the statement Regional Nature Park (RNP) XY contributes to the good image of agricultural products and services in the RNP and participation in at least one of the RNP activities ( $n=363)$, (illustration by the authors).

contribution to the image and promotion of regional agricultural products as an important advantage (see Figure 3). Representatives from agriculture and RNPs considered communication about regional products one of the main tasks of a RNP and saw further potential to enhance RNP activities in this area. Many were in favour of the Swiss RNP product label, but they would like to see its implementation simplified.

$3^{\text {rd }}$ path of action: Creation of regional value chains

According to our results, farmers hoped that RNPs would be able to support the creation of regional value chains and new sales opportunities that would increase their margins. The interviewed farmers considered it an important role of RNPs to act as mediator and networker when creating these regional value chains. The questions that arise are: How could farmers who do not yet sell products locally profit from value chain creation? And how could farmers who are already successful in direct marketing also benefit from the RNP? $4^{\text {th }}$ path of action: Use of agricultural support instruments

The evaluation of the online survey confirmed that in all three RNPs the majority of the interviewed farmers participated in projects that support them in preserving biodiversity and traditional cultural landscapes and also bring them direct financial benefits as a result of being linked to the direct payment subsidy system: $84 \%$ Binntal $(n=13), 73 \%$ Gantrisch, $(n=201)$ and $57 \%$ Schaffhausen $(n=139)$. From these results it can be deduced that RNPs should clarify to what extent they could communicate or use agricultural support instruments in order to more successfully involve the agricultural population in RNP activities.

\section{$5^{\text {th }}$ path of action: Communication between farmers and RNP management}

Our results indicate that farmers should be provided with (even) more information about the options for involvement, participation and development. From

\begin{tabular}{|c|c|c|c|c|}
\hline $\begin{array}{l}1^{\text {st }} \text { round of } \\
\text { workshops in the } \\
3 \text { parks ( } \& \\
\text { Romandy) }\end{array}$ & $\begin{array}{c}\text { Internal } \\
\text { workshop to } \\
\text { develop ideas }\end{array}$ & $\begin{array}{l}\text { Develop ideas } \\
\text { further }\end{array}$ & $\begin{array}{l}\text { d round of } \\
\text { kshops in the } \\
3 \text { parks }\end{array}$ & $\begin{array}{l}\text { Final selection of } \\
\text { tools and } \\
\text { approaches, } \\
\text { completion }\end{array}$ \\
\hline \multirow{2}{*}{$\begin{array}{l}\text { Presentation of results } \\
\text { from the preliminary } \\
\text { study } \\
\text { Presentation and } \\
\text { discussion of the paths of } \\
\text { action }\end{array}$} & \multirow{2}{*}{$\begin{array}{l}\text { Development of "How } \\
\text { might we ...?" questions } \\
\text { based on challenges and } \\
\text { formulated insights } \\
\text { Brainstorming of ideas on } \\
\text { the developed questions }\end{array}$} & \multirow{2}{*}{$\begin{array}{l}\text { Further development of } \\
\text { selected ideas } \\
\text { AGRIDEA-internal } \\
\text { feedback on them }\end{array}$} & \multirow{2}{*}{$\begin{array}{l}\text { Development of questions } \\
\text { and ideas based on the } \\
\text { challenges of the } \\
\text { respective park \& } \\
\text { feedback on the } 7 \text { ideas } \\
\text { for measures developed } \\
\text { by the project team }\end{array}$} & \multirow{2}{*}{$\begin{array}{l}\text { Final selection of the best } \\
\text { ideas/approaches by } \\
\text { AGRIDEA } \\
\text { Further elaboration and } \\
\text { finalization }\end{array}$} \\
\hline & & & & \\
\hline $\begin{array}{l}\text { Results } \\
\text { Feedback on the following } \\
\text { fields of action categories: } \\
\text { - Challenges } \\
\text { - Concerns } \\
\text { - Insights/ideas } \\
\text { - Sticking points } \\
- \text { Resources } \\
\text { - Information }\end{array}$ & $\begin{array}{l}\text { Results } \\
\text { Collection and evaluation } \\
\text { of ideas on the following } \\
\text { topics: } \\
\text { - Participation } \\
\text { - Marketing } \\
\text { - Identification } \\
\text { - Nature park product } \\
\text { label } \\
\text { - Role of the park }\end{array}$ & $\begin{array}{l}\text { Results } \\
7 \text { ideas for the 2nd round } \\
\text { of workshops: } \\
\text { - Idea channel } \\
\text { (innovation support) } \\
\text { for parks } \\
\text { - Course series } \\
\text { agriculture - park } \\
\text { - Compile tips, tricks \& } \\
\text { information } \\
\text { - Establish regular ex- } \\
\text { change of experiences } \\
\text { - Taster days } \\
\text { - Agriculture-Park } \\
\text { excursion } \\
\text { - Best practices }\end{array}$ & $\begin{array}{l}\text { Results } \\
\text { - Park-specific ideas for } \\
\text { better integration of } \\
\text { agriculture } \\
\text { - Feedback on the } 7 \\
\text { ideas developed by the } \\
\text { project team }\end{array}$ & $\begin{array}{l}\text { Proposed measures } \\
\text { - Implementation of a } \\
\text { platform for sharing } \\
\text { experience (face-to- } \\
\text { face) } \\
\text { - Integration of best } \\
\text { practices, thematic } \\
\text { inputs and coaching on } \\
\text { this platform } \\
\text { - Agripedia page for } \\
\text { selected content }\end{array}$ \\
\hline
\end{tabular}
the online survey it was clear that farmers consider

Figure 4 - Illustration of the process for developing approaches to better integrate agriculture into Regional Nature Parks and the concrete results from each individual step in the process. 
their level of knowledge about the RNP to be rather low. $66 \%$ of the respondents declared that they felt only partially or ill-informed about the activities of the RNP ( $n=363)$. Therefore it would be useful to know how farmers could be better informed about the RNP, taking into account their interview responses that indicated they do not have sufficient time to obtain information themselves.

\section{$6^{\text {th }}$ path of action: Structural integration}

According to the results from the guided interviews, structural integration of farmers in RNPs is an important approach to enhance cooperation between RNPs and their farmers. In addition to the integration of agriculture into the existing bodies of the RNPs, the sort of organizational structures that already exist in some of the three RNPs that are specifically aimed at the agricultural population would certainly help to achieve this goal.

\section{Results from the $2^{\text {nd }}$ phase: Development of approaches}

In an initial round of workshops, the results of the pre-study and the paths of action were presented and explored in greater depth (see Figure 4). Challenges and sticking points as well as insights and initial ideas for solutions were established that then served as a basis for the development of concrete approaches.

These first workshops already provided the impetus for initial activities in the RNPs: For example, two ideas from the workshop in Gantrisch RNP were implemented: 1) establishing contact between the RNP management and the agricultural advisory services, and 2) holding a workshop to specify opportunities for collaboration.

The challenges and ideas discussed in the first workshops served as a basis to develop possible approaches that could be used to integrate agriculture better into several RNPs. For this purpose, based on jointly identified challenges, insights and then questions were formulated. Afterwards we formulated ideas in response to these questions, with the most promising ideas being further developed. In this way, a total of seven ideas for possible approaches emerged, ranging from educational measures to sharing experiences and support for innovation (for all 7 ideas of the $2^{\text {nd }}$ round of the workshop, see Figure 4) for the $2^{\text {nd }}$ round of the workshops. Presentation of the above-mentioned seven approaches and joint evaluation of them in these workshops.

\section{Exchange instead of ready-made approach- es}

One of the developed approaches received more support than the others - the platform for regular sharing of experiences between stakeholders from agriculture and the RNPs. Since many of the other ideas discussed in the second round of workshops, such as the presentation of best practices, elements from the course series, excursions, etc., could be integrated into such an exchange platform, it was decided to drop the idea of developing more tangible approaches and to focus on the implementation of this platform, which is being organized by AGRIDEA and the Network of Swiss RNPs. A first event took place under the title Cooperation as an Opportunity on 7 September 2021 in Gantrisch RNP.

In addition, a simple online publication was created that presents the project, the developed paths of action and possible approaches for better integration of agriculture into RNPs, which can be expanded in future, if needed.

It is not surprising that the decision was made in favour of a platform for regular sharing of experiences. According to our results, the integration of agriculture into RNPs is a complex challenge for which there are no ready-made, one-size-fits-all solutions. In such a context, the main challenge is to bring together a wide range of stakeholders who work together to find appropriate solutions; a task that should be understood as an ongoing process. From this point of view, a regular platform for sharing experiences will hopefully create a suitable framework to develop a variety of solutions for better integration of agriculture into RNPs.

\section{References}

Butticaz, M. 2013. Vor- und Nachteile eines Regionalen Naturparks aus der Perspektive der LandwirtInnen. Am Beispiel des Regionalen Naturparks Gruyère Pays-d'Enhaut. Universität Zürich.

Haggenmacher, M. 2017. Landwirtschaft und Naturschutzprojekte. Eine Untersuchung zur Wabrnehmung der Landwirtinnen und Landwirte am Beispiel des Nationalparkprojekts Parc Adula. Universität Zürich.

Humer-Gruber, A. 2016. Farmers' perception of a mountain biosphere reserve in Austria. Mountain Research and Development 36(2): 153-161. Doi: 10.1659/ MRD-JOURNAL-D-15-00054.1

IDEO.org 2015. The Field Guide to Human-centered Design. Available at: https://www.designkit.org/resources/1 (accessed: 27/09/2021)

Trachsel, S., R. Göpfert, B. Koster, R. Moser, D. Mettler \& B. Reutz 2020. AgriPark: Grundlagen für eine erfolgreiche Einbindung der Landwirtschaft in Regionalen Naturpärken: Ergebnisse aus einer standardisierten OnlineBefragung der landwirtschaftlichen Bevölkerung und Leiffadeninterviews in drei Naturpärken - Landschaftspark. Wädenswil: ZHAW Zürcher Hochschule für Angewandte Wissenschaften. Doi: 10.21256/zhaw-22946

Snowden, D. \& M. Boone 2007. A Leader's Framework for Decision Making. Harvard Business Review. November 2007, 69-76. Available at: https://hbr. org/2007/11/a-leaders-framework-for-decisionmaking (accessed: 27/09/2021) 


\section{Authors}

\section{Sonja Trachsel}

is a researcher at the Institute of Natural Resource Science of the ZHAW University of Applied Sciences. Her research interests are in the fields of sustainable rural development and social impact of food value chains. E-mail: sonja.trachsel@zhaw.ch

\section{Ruth Moser ${ }^{2}$}

is a trainer as well as co-team leader of the training \& rural advisory team at AGRIDEA. She offers training in methodologies like participation and innovation support and is responsible for the areas: innovation, organizational development and participative methods. E-mail: ruth.moser@agridea.ch

Birgit Reutz'

is a lecturer and researcher at the Institute of Natural Resource Science of the ZHAW University of Ap- plied Sciences. Her research interests are in the field of sustainable development, RNPs and the participation of local actors. E-mail: birgit.reutz@zhaw.ch

\section{Rebecca Göpfert'}

is a lecturer and leader of the research group tourism and sustainable development at the Institute of Natural Resource Science of the ZHAW in Wergenstein. Her research interests are in the field of sustainable development in rural areas with a focus on sustainable tourism, agriculture and the development of value chains. E-mail. rebecca.goepfert@zhaw.ch

${ }^{1}$ Zurich University of Applied Sciences ZHAW; Institute of Natural Resource Sciences, Grüentalstrasse 14, 8820 Wädenswil (Switzerland)

${ }^{2}$ AGRIDEA - Swiss Association for the Development of Agriculture and Rural Areas, Training \& Rural Advisory Team, Eschikon 28, 8315 Lindau (Switzerland) 